\title{
THE MEDIATING ROLE OF OPTIMISM IN RELATION BETWEEN WISDOM \& KNOWLEDGE VIRTUES AND SCHOOL WELL-BEING IN ADOLESCENCE
}

\author{
Bagus Hary Prakoso ${ }^{1}$, Zulmi Ramdani ${ }^{2}$, Asrijanty Asrijanty ${ }^{1}$, Rahmawati Rahmawati ${ }^{1}$, \\ Safari Safari ${ }^{1}$, Heni Waluyo Siswanto ${ }^{3}$ and Nina Purnamasari ${ }^{3}$ \\ ${ }^{l}$ Center for Assessment and Learning, Ministry of Education and Culture \\ Jl. Gunung Sahari Raya No. 4, Jakarta, 10710, Indonesia \\ ${ }^{2}$ Faculty of Psychology, UIN Sunan Gunung Djati Bandung \\ Jl. A.H. Nasution No. 105, Cibiru-Bandung, Indonesia \\ ${ }^{3}$ Center for Curriculum and Book, Ministry of Education and Culture \\ Jl. Gunung Sahari Raya No. 4, Jakarta, 10710, Indonesia
}

\begin{abstract}
School well-being for adolescents is a condition that is expected to be one form of educational success. Many personal factors certainly play a role in producing the well-being include positive character of the student. This study aims to look at the role of optimism in mediating the influence of wisdom \& knowledge virtues consisting of the character of creativity, curiosity, open-mindedness, love of learning, and perspective on school well-being. The quantitative research design was used involving 339 respondents selected by non-probability sampling techniques. The results showed that optimism plays a significant role as a mediator of creativity, curiosity, open-minded, and love of learning for school well-being adolescents. While the strength of character curiosity, creativity, open-mindedness, and perspective become significant predictors that influence optimism itself. This study explains that the importance of developing these positive characters in daily activities at school.
\end{abstract}

\section{KEYWORDS}

Adolescence, Character, Optimism, Positive Psychology, School Well-being, Wisdom and Knowledge Virtues

\section{INTRODUCTION}

Adolescence is a stage of development which certainly involves a variety of psychological challenges and demands that must be resolved properly. For adolescents, school is one of the places they spend at that time to develop the positive potential they have, so it becomes important when school becomes a place other than at home, for them to get happiness in their life development (Ramdani, Amrullah and Tae, 2019). The concept of school well-being is often the best indicator that can determine whether schools provide fun things so that youth become individuals who are said to be prosperous (Heller-sahlgren, 2017; Dillon et al., 2020; McCalman et al., 2020).

School well-being certainly occurs because of various internal and external factors. External factors refer to the theoretical dimensions of school well-being such as the availability of complete and supportive facilities in schools, programs that upgrade the interests and talents of adolescents, as well as positive relationships and communication between teachers and young people themselves (Konu and Rimpelä, 2002; Ramdani and Prakoso, 2019). Meanwhile, internal factors involving positive characters possessed by adolescents also determine the formation of school well-being in adolescents. Theoretically, many internal factors that determine the success of adolescents in getting a school well-being are wisdom and knowledge virtues (Toner et al., 2012; Banicki, 2014). In the context of positive psychology, wisdom and knowledge virtues are the personal parts of individuals whose function is to direct them into individuals who have a wise mindset, full of consideration when facing problems, serious in the learning process and try as much as possible to get good knowledge. Then the personal part is manifested into 5 characters, namely creativity, curiosity, open-mindedness, love of learning, and perspective (Peterson and Seligman, 2004). 
The strengths of character which are part of the wisdom and knowledge virtues are considered unable to directly influence the formation of adolescent school well-being (Gillham et al., 2011). In this case there are other variables that become mediators between wisdom and knowledge virtues towards school well-being. The author assumes that optimism is an effective mediating variable in mediating the relationship between wisdom and knowledge virtues and school well-being. Theoretically, these variables are included in the construction of positive psychology which will produce a significant correlation in the relationship (Martínez-Martí and Ruch, 2017). In addition, previous studies also confirmed that optimism is a condition when individuals already know well that the strengths of character needed in the learning process are felt deeply by the individual, so that the strength of these characters will produce an optical condition for what individuals have which will ultimately create their well-being in the context of education (Smokowski et al., 2014; Chen et al., 2016). Theoretically, optimism plays a significant role in directing a person's individual potential towards achieving happiness and well-being. This reasoning refers to the statement that these good potentials must be channeled first into a positive container and are able to pass them on to the intended goals. This study itself aims to see the role of optimism as a mediator of the relationship between wisdom and knowledge virtues towards school well-being. Specifically, these wisdom and knowledge virtues are manifested in the 5 characters described earlier. Thus based on theoretical exposure and interconnection between variables in the study, the authors propose the hypothesis that optimism can be an effective mediator that mediates the relationship between the strength of character in wisdom and knowledge virtues towards adolescent school well-being. More clearly, the relationship between the three variables can be seen in Figure 1.

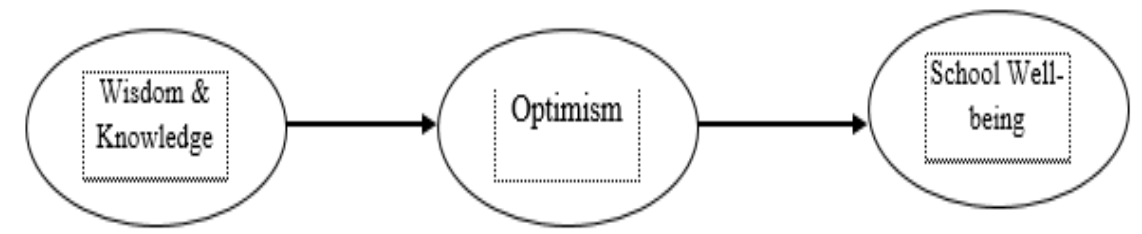

Figure 1. Theoretical Model Optimism as Mediator between Wisdom \& Knowledge toward School Well-being

\section{CONCEPTUAL FRAMEWORK}

\subsection{Wisdom and Knowledge Virtues}

Wisdom can be defined as "the power of judging correctly and following the healthiest actions, based on knowledge, experience, understanding, etc"(Ahamed, 2017). There are several reasons why it is important to develop wisdom in school settings. First, the purpose of schools should not only be to provide knowledge, but to help students develop the wise use of that knowledge. Knowledge can be used for better or worse purposes, and schools must help students use their knowledge for good. Second, the teaching of wise thinking is always implicit in the school curriculum in any case. Third, if adults do not make wise decisions, schools may deserve a share of mistakes if they never prepare adults today to make such decisions (Park, Peterson and Al, 2004; Peterson and Seligman, 2004).

Wisdom and knowledge virtues are divided into 5 strengths of character, namely creativity, curiosity, open-mindedness, love of learning, and perspective (Peterson and Seligman, 2004). Creativity refers to the nature of individuals to discover new things, create other opportunities, and solve problems with alternative ideas. Curiosity is a character associated with a great tendency to find out all the information that is important in accordance with the purpose of individual life. Then, open-mindedness focuses on the openness of one's attitude, thoughts, and desire to get new information and important new things. The love of learning character leads someone to be serious about learning and gaining knowledge. And finally the perspective character directs individuals to have an ideal and firm attitude towards the circumstances that should occur in life. These five characters will be important for individuals to succeed in the field of education (Park, Peterson and Al, 2004; Sternberg, 2010).

\subsection{School-wellbeing}

The school well-being model is based on Allardt's sociological well-being theory and values well-being as an entity in school settings (Konu and Rimpelä, 2002; Konu et al., 2002). Well-being is a state in which it is 
possible for humans to fulfill their basic needs. Well-being is connected with teaching and education, and with learning and achievement. School well-being indicators are divided into four categories: school conditions (having) which refer to material conditions and impersonal needs in a broad perspective; social relations (loving) means the need to relate to other people and to form social identities; the means for self-fulfillment (being) indicate the need for personal growth, that is, integration into society and living in harmony with nature; and health status (health).

\subsection{Optimism}

Optimists are people who expect good things to happen to them. Whereas pessimists, on the other hand, expect bad things to happen to them. People who are optimistic and pessimistic have a different perspective on the world, including how they face problems, overcome difficulties, and differ in their resources, both social and socio-economic. The nature of optimism can provide cognitive, coping, and contextual resources that improve mental health.

The scientific definition of optimism and pessimism focuses on expectations for the future. Theory that is close to the concept of optimism is the motivation theory known as expectancy-value (Carver, Scheier and Segerstrom, 2010). Expectancy-value theory assumes that individuals are set by goals which are desirable actions and expectation are self-confidence or doubt in the achievement of something. The more important the goals given to the person, the greater the value (Carver, Scheier and Segerstrom, 2010). If people doubt that they can achieve a goal, then they might withdraw efforts in that direction. They may stop prematurely, or even they will never take an action. While those who believe that they can achieve results they will survive even when faced with great difficulties.

\section{METHOD}

\subsection{Design \& Participant}

The author uses a quantitative approach to answer the research hypotheses proposed in this study. A set of questionnaires was distributed to a selected number of respondents involved in the study using a non-probability sampling technique with a purposive sampling technique selection specification (Warsihna, Ramdani and Prakoso, 2019). Characteristics of respondents involved in this study are those who are currently studying junior high school and senior high school in the city of Bandung with an age range of 12 to 18 years. All respondents involved agreed with informed consent that proves that they participated in the research voluntarily and without coercion.

\subsection{Instruments}

This study uses 3 measuring devices that represent 3 variables in the study. The first measuring instrument is Value in Action Inventory Scales (VIA-IS) which is used to measure wisdom and knowledge virtues instruments as an independent variable in research. Furthermore, the second measuring tool, the School Well-being Instrument, is used to measure the welfare conditions of respondents at school as the dependent variable. Meanwhile, the third measuring instrument is the Optimism Scale which is used to measure the mediator variables in this study.

\subsubsection{Wisdom and Knowledge Virtues}

o measure wisdom and knowledge virtues, the writer uses the Value in Action Inventory Scales (VIA-IS) measuring instrument which was originally used by Peterson and Seligman (2004) to describe the strengths of individuals. Wisdom and knowledge virtues consist of 50 items that measure 5 character strengths namely creativity, curiosity, open mindedness, love of learning, and perspective, where each character is represented by 10 items in it. The author uses the instrument in the Indonesian version which has been modified by Fahmi and Ramdani (2014) dan Ramdani, Amrullah, and Tae, (2019), while still referring to the same number of items as the original gauge. The reliability coefficient values for each character strengths in this 
study are creativity $(\alpha=.787)$, curiosity $(\alpha=.749)$, open-mindedness $(\alpha=.802)$, love of learning $(\alpha=.739)$, and perspective $(\alpha=.787)$. As for the 50 different item power values are $.249-.636$.

\subsubsection{School Well-Being}

To measure school well-being, the writer uses a measurement made by Ramdani and Prakoso (2019), by constructing the main theory put forward by Konu, Alanen, Lintonen, \& Rimpelä, (2002); Konu, Lintonen, and Rimpelä (2002); Konu and Rimpelä (2002). The instrument measures 4 dimensions in school well-being, having, being, loving, and health. The number of items in the gauge is 26 items representing the four dimensions of the school well-being. The psychometric property for measuring school well-being that has a reliability coefficient of $(\alpha) .862$, with a range of different power values of $.281-.559$.

\subsubsection{Optimism}

To measure the condition of optimism in respondents, the authors refer to the theories conveyed by Scheier, Carver, and Bridges (1994 in Augustiya, Nurislamiaty, Al-fatoni, \& Rachma (2019). Optimism in individuals can be measured by looking at behavioral indicators that appear including positive aspects and negative aspects. This study uses a measurement tool in the Indonesian version which has been modified into 14 items that measure positive aspects and negative aspects on the optimism scale (Augustiya et al., 2019). The instrument used has a reliability coefficient $(\alpha)$ of .715 with discriminatory power reaching .300 to .478 .

\subsection{Data Collection and Analysis}

The author collects data offline by distributing all instruments directly to selected respondents. Then proceed with tabulating data for analysis. Data analysis uses SPSS software to get descriptive statistical results from existing data and Lisrel software to test hypotheses by looking at the function of each variable in a research model.

\subsection{Preliminary Analysis}

For school well-being data that is used refers to descriptive data with an average value of 92.4 and a standard deviation of 10.1. Then obtained low, medium, and high categories of respondents. The low category is those who have a score below 82.3 , those who are medium are with a score from 82.3 to 102.5 , and those in the high category are those who have a score above 102.5. Researchers conducted a Chi Square test to see whether age and sex differences in subjects played a role in increasing or decreasing school well-being in respondents. Chi Square test results for the respondent's age data showed .083 ( $p>0.05$ ), and for gender data the results obtained were $.924(p>.05)$. Both of these data, both age differences and gender differences did not play a role in increasing and decreasing school well-being in respondents.

\section{RESULTS \& DISCUSSION}

The data collection process is carried out for one week while maintaining the code of ethics in psychological research. The number of respondents involved in the study was 339 respondents (see table 1).

Table 1. Demographic Features of Respondents

\begin{tabular}{|c|c|c|c|}
\hline No. & Category & $\mathrm{N}$ & Percentage \\
\hline \multirow[t]{3}{*}{1} & SEX & & \\
\hline & Male & 168 & 49.6 \\
\hline & Female & 171 & 50.4 \\
\hline \multirow[t]{8}{*}{2} & AGE & & \\
\hline & 12 years & 20 & 5.9 \\
\hline & 13 years & 59 & 17.4 \\
\hline & 14 years & 103 & 30.4 \\
\hline & 15 years & 70 & 20.6 \\
\hline & 16 years & 67 & 19.8 \\
\hline & 17 years & 18 & 5.3 \\
\hline & 18 years & 2 & 0.6 \\
\hline
\end{tabular}




\begin{tabular}{|c|c|c|c|}
\hline No. & Category & $\mathrm{N}$ & Percentage \\
\hline \multirow[t]{8}{*}{3} & ETHNIC & & \\
\hline & Sunda & 266 & 78.5 \\
\hline & Jawa & 44 & 13 \\
\hline & Batak & 9 & 2.7 \\
\hline & Minang & 7 & 2.1 \\
\hline & Betawi & 5 & 1.5 \\
\hline & Melayu & 3 & 0.9 \\
\hline & Aceh/Bugis/Gorontalo/Kendari & 1 & 1.2 \\
\hline \multirow[t]{4}{*}{4} & RELIGION & & \\
\hline & Islam & 334 & 98.5 \\
\hline & Kristen & 4 & 1.2 \\
\hline & Catholic & 1 & 0.3 \\
\hline
\end{tabular}

Note: S.E. (Standard. Error). Est./S.E. (Estimate for Standard Error). (* Significant).

As explained in table 1, the difference in the number of respondents by sex is very small, only 3 people differ where the female teenage respondents are slightly more than the male. The age of respondents is dominated by the age of 14 years which reaches $30.4 \%$ of the total respondents. Meanwhile, the largest ethnic group in this study came from Sundanese, which reached almost $78.5 \%$ of the total respondents. This is a natural thing because the locus of this research was conducted in the city of Bandung, which is historically and culturally the origin of the Sundanese. Furthermore, the authors conducted a correlation analysis to see how the relationships between the variables in this study can be seen in table 2 .

Table 2. Correlation between variables

\begin{tabular}{cllccccccccc}
\hline No. & & Variable & 1 & 2 & 3 & 4 & 5 & 6 & 7 & 8 \\
\hline 1 & Creativity & 1 & .476 & .508 & .348 & .504 & .743 & .502 & .292 \\
2 & Curiosity & .476 & 1 & .460 & .482 & .461 & .766 & .515 & .399 \\
3 & Open-Mindedness & .508 & .460 & 1 & .452 & .551 & .780 & .540 & .426 \\
4 & Love of learning & .348 & .482 & .452 & 1 & .423 & .719 & .455 & .384 \\
5 & Perspective & .504 & .461 & .551 & .423 & 1 & .777 & .481 & .370 \\
6 & Wisdom \& Knowledge Virtues & .743 & .766 & .780 & .719 & .777 & 1 & .658 & .495 \\
7 & School well-being & .502 & .515 & .540 & .455 & .481 & .658 & 1 & .620 \\
8 & Optimism & .292 & .399 & .426 & .384 & .370 & .495 & .620 & 1 \\
\hline
\end{tabular}

Note. All correlation are significant.

Table 2 presents information related to the correlation coefficient obtained by each variable in this study. Referring to the correlation results in table 2, almost all correlation values have a score above .3. This shows that theoretically, all variables involved in this study are variables that have a linear research construct. Next to see the test results on the role of the mediator variable in mediating the independent variables on the dependent can be seen in tables 3 and 4. Table 3 explains the role of the variable directly meaning without the mediator, while table 4 explains the role of the variable indirectly or the role of the mediator in research.

Table 3. Direct Effect of Variable

\begin{tabular}{|c|c|c|c|c|}
\hline Variable & Estimate & S.E. & Est./S.E. & P-Value \\
\hline \multicolumn{5}{|l|}{ School Well-being ON } \\
\hline Optimism & .455 & .058 & 7.910 & $.000 *$ \\
\hline Creativity & -.074 & .057 & -1.299 & .194 \\
\hline Curiosity & .101 & .056 & 1.796 & .072 \\
\hline Open-Mindedness & .045 & .060 & .750 & .454 \\
\hline Love of Learning & .113 & .052 & 2.182 & $.029 *$ \\
\hline Perspective & .016 & .056 & .280 & .780 \\
\hline \multicolumn{5}{|l|}{ Optimism ON } \\
\hline Creativity & .250 & .049 & 5.146 & $.000 *$ \\
\hline Curiosity & .180 & .049 & 3.677 & $.000 *$ \\
\hline Open-Mindedness & .304 & .050 & 6.129 & $.000 *$ \\
\hline Love of Learning & .131 & .046 & 2.882 & $.004 *$ \\
\hline Perspective & .030 & .049 & .610 & .542 \\
\hline
\end{tabular}

Note: S.E. (Standard. Error). Est./S.E. (Estimate for Standard Error). (* Significant). 
Table 4. Indirect Effect of Variable (Mediator Effect)

\begin{tabular}{lcccc}
\hline \multicolumn{1}{c}{ Variable } & Estimate & S.E. & Est./S.E. & P-Value \\
\hline Wisdom \& Knowledge to SWB & & & & $.000^{*}$ \\
Creativity & .114 & .027 & 4.256 & $.001^{*}$ \\
Curiosity & .082 & .025 & 3.335 & $.000^{*}$ \\
Open-Mindedness & .138 & .029 & 4.800 & $.007^{*}$ \\
Love of Learning & .060 & .022 & 2.714 & .543 \\
Perspective & .014 & .023 & .608 & .53 \\
\hline
\end{tabular}

Note: S.E. (Standard. Error). Est./S.E. (Estimate for Standard Error). (* Significant). SWB (School Well-being).

The information obtained in table 3 explains that optimism significantly influences school well-being $(p<.05)$. While the variables of creativity, curiosity, open-mindedness, and perspective do not have a significant effect on school well-being if done on the direct path $(p>.05)$. Only the love of learning variable has a direct effect on school well-being. Whereas the indirect pathway (table 4) shows that the optimism variable acts as a mediator of the influence of the variables of creativity, curiosity, open-mindedness, and love of learning on school well-being $(p<.05)$. The role of the mediator does not function in mediating the effect of perspective variables on school well-being.

The results of the study in general showed that the mediator in this study had a significant role in mediating the influence of various character strengths that exist in wisdom and knowledge virtues on school well-being. These results support several previous studies that also convey the same information that effective optimism mediates the strength of personal character possessed by individuals towards increasing their happiness and well-being (Malinowski and Lim, 2015). Optimism itself is certainly a positive psychological variable has a linear relationship with other positive characters such as school well-being. Theoretically, the two variables are part of a positive character that if the correlation between the two will produce significant results and is directly proportional. This means that when individuals have high optimism it can improve their welfare in any context (Ho, Cheung and Cheung, 2010; Kimberly, Laura and Elizabeth, 2010).

If referring to table 2 , each variable has a high and significant relationship. This can be seen by the magnitude of the correlation coefficient values obtained more than .3 (Ramdani, 2018). Correlations for each strength of character and optimism include creativity-optimism $(r=.502)$, curiosity-optimism $(r=.515)$, open-mindedness-optimism $(r=.540)$, love of learning-optimism $(r=.455)$, and perspective-optimism $(r=.482)$. The correlation between the 5 characters with optimism shows positive and linear results, meaning that the greater the strength of character in adolescents, the greater the likelihood of them to be optimistic about what they have. Likewise the relationship with optimism and school-wellbeing is shown by a correlation value of $r=.680$, which also shows that the higher optimism that exists in adolescents will produce high school well-being as well. Thus, the results of table 2 support the existing research model that the role of a mediator relationship between independent and dependent can be optimal if the correlation between the variables involved is also significant (Fairchild and McQuillin, 2010; Jaenudin et al., 2020; Ramdani, Marliani and Rahman, 2019).

Meanwhile, tables 3 and 4 explain how the mediator's role functions in research. Table 3 shows the direct influence of the strength of wisdom and knowledge virtues character on school-well-being. Of the 5 existing character strengths, only the love of learning character is significant for school well-being $(p<.05)$, while the other 4 characters namely creativity, curiosity, open-mindedness, and perspective do not directly influence school well-being. This means that the four characters need mediator variables so that their influence can be significant on school well-being. Meanwhile for perspective character (table 3), it is the only character that has no effect on optimism $(p>.05)$, if tested on the direct path so that these results indicate that the existence of perspective is not able to present the optimism situation for adolescents in this study. Thus, if it is continued on indirect analysis or through mediators, optimism plays an effective role as a mediator of the character of creativity, curiosity, open-mindedness, and love of learning towards school well-being. This can be seen in table 4 which shows the 4 strengths of characters that have an appropriate P-Value $(p<.05)$, with details of creativity $(p=.000)$, curiosity $(p=.001)$, open-mindedness $(p=.000)$, and love of learning $(p=.007)$.

This study certainly supports the results of previous studies which assume that optimism acts as an effective mediator in the relationship between character strength and well-being. Even well-being in a school context is also largely determined by the optimal psychological situation when adolescents truly believe that the good things they will get during the learning process. In this study, only the love of learning character can significantly influence school well-being either directly or indirectly. This fact is also supported by 
theoretical assumptions which state that a person's tendency to succeed in school is largely determined by his desire and seriousness in learning, which is operationally manifested in the achievement of learning achievement so that his influence can be directly or indirectly on school well-being. Likewise, with perspective being the only variable that does not affect school well-being through optimism. That is because since direct influence, perspective has no significant effect on optimism so it also has no effect on school well-being through optimism.

This study explains the significant correlation between the variables tested. Optimism as a mediating variable certainly plays an important role in explaining the relationship between character identities possessed by individuals and the happiness or well-being felt by students at school. By adding more respondents, it is hoped that in the future they can provide more definite recommendations regarding internal and external factors that must be directly controlled by any party to create optimal conditions for school well-being. The use of the measured experimental method is also expected to be applied in future research, so that it can also strengthen the existence of dependent variables. In the future, it is also necessary to develop measuring instruments that are more in line with the developmental conditions of the respondents if it is to be carried out at the age of children, because it will be faster to anticipate the factors that need to be considered in their development.

\section{CONCLUSION}

The results of this study indicate that optimism acts as a significant mediator in the relationship between wisdom and knowledge virtues towards school well-being. Specifically optimism mediates the strength of character in wisdom and knowledge which includes creativity, curiosity, open-mindedness, and love of learning towards school well-being. Thus, these results indicate that the optimization of the strength of character will be the main source for adolescents to create effective optimism that will ultimately make them well-being.

\section{ACKNOWLEDGEMENT}

This study is the result of routine collaboration conducted by the Center for Assessment and Learning, Ministry of Education and Culture of the Republic of Indonesia with the Faculty of Psychology of UIN Sunan Gunung Djati Bandung. We would like to thank all the respondents involved in the research, especially for SMPN 44 Bandung, SMP Tunas Unggul Bandung, and SMAN 8 Bandung for helping to facilitate the authors to retrieve data during the process.

\section{REFERENCES}

Ahamed, S. V. (2017) 'Knowledge and Wisdom Across Cultures', Evolution of Knowledge Science, pp. 5-21. doi: 10.1016/b978-0-12-805478-9.00001-7.

Augustiya, T. et al. (2019) 'Hubungan orientasi karier dengan optimisme pada mahasiswa jurusan keagamaan UIN Sunan Gunung Djati Bandung', Jurnal Psikologi Islam dan Budaya, 2(1), pp. 31-42. doi: 10.15575/jpib.v2i1.4014.

Banicki, K. (2014) 'Positive psychology on character strengths and virtues. A disquieting suggestion', New Ideas in Psychology. Elsevier Ltd, 33(1), pp. 21-34. doi: 10.1016/j.newideapsych.2013.12.001.

Carver, C. S., Scheier, M. F. and Segerstrom, S. C. (2010) 'Optimism', Clinical Psychology Review, 30(7), pp. 879-889. doi: 10.1016/j.cpr.2010.01.006.

Chen, W. et al. (2016) 'Socioeconomic status and life satisfaction in Chinese adolescents: Analysis of self-esteem as a mediator and optimism as a moderator', Personality and Individual Differences. Elsevier Ltd, 95, pp. 105-109. doi: 10.1016/j.paid.2016.01.036.

Dillon, A. et al. (2020) 'Support for Aboriginal and non-Aboriginal Australian students' wellbeing at school', International Journal of Educational Research. Elsevier, 99(November 2019), p. 101520. doi: 10.1016/j.ijer.2019.101520.

Fahmi, I. and Ramdani, Z. (2014) 'Profil kekuatan karakter dan kebajikan pada mahasiswa berprestasi', Psympathic: Jurnal Ilmiah Psikologi, 1(1), pp. 98-108. doi: https://doi.org/10.15575/psy.v1i1.471. 
Fairchild, A. J. and McQuillin, S. D. (2010) 'Evaluating mediation and moderation effects in school psychology: A presentation of methods and review of current practice', Journal of School Psychology. Society for the Study of School Psychology, 48(1), pp. 53-84. doi: 10.1016/j.jsp.2009.09.001.

Gillham, J. et al. (2011) 'Character strengths predict subjective well-being during adolescence', Journal of Positive Psychology, 6(1), pp. 31-44. doi: 10.1080/17439760.2010.536773.

Heller-sahlgren, G. (2017) 'Smart but Unhappy: Independent-school Competition and the Wellbeing-efficiency Trade-off in Education', Economics of Education Review. Elsevier Ltd. doi: 10.1016/j.econedurev.2017.10.005.

Ho, M. Y., Cheung, F. M. and Cheung, S. F. (2010) 'The role of meaning in life and optimism in promoting well-being', Personality and Individual Differences. Elsevier Ltd, 48(5), pp. 658-663. doi: 10.1016/j.paid.2010.01.008.

Jaenudin, U. et al. (2020) 'Work-family conflict toward marital satisfaction with self-efficacy as a moderator variable', Humanities \& Social Sciences Reviews, 8(2), pp. 373-380. doi: 10.18510/hssr.2020.8242.

Kimberly, R., Laura, D. and Elizabeth, M. (2010) 'Stress, Self-Esteem, Hope, Optimism, and Well-Being in Urban, Ethnic Minority Adolescents', Journal of Multicultural Counseling and Development, 38(April), pp. 99-111.

Konu, A. et al. (2002) 'Factor structure of the School Well-being Model', Health Education Research, 17(6), pp. 732-742. doi: 10.1093/her/17.6.732.

Konu, A. I., Lintonen, T. P. and Rimpelä, M. (2002) 'Factors associated with schoolchildren's general subjective well-being', Health Education Research, 17(2), pp. 155-165. doi: 10.1093/her/17.2.155.

Konu, A. and Rimpelä, M. (2002) 'Well-being in schools: a conceptual model', Health Promotion International, 17(1), pp. 79-87. doi: 10.1093/heapro/17.1.79.

Malinowski, P. and Lim, H. J. (2015) 'Mindfulness at Work: Positive Affect, Hope, and Optimism Mediate the Relationship Between Dispositional Mindfulness, Work Engagement, and Well-Being', Mindfulness, 6(6), pp. 1250-1262. doi: 10.1007/s12671-015-0388-5.

Martínez-Martí, M. L. and Ruch, W. (2017) 'Character strengths predict resilience over and above positive affect, self-efficacy, optimism, social support, self-esteem, and life satisfaction', Journal of Positive Psychology, 12(2), pp. 110-119. doi: 10.1080/17439760.2016.1163403.

McCalman, J. et al. (2020) “'It's all about relationships": The place of boarding schools in promoting and managing health and wellbeing of Aboriginal and Torres Strait Islander secondary school students', Children and Youth Services Review. Elsevier, 113(April), p. 104954. doi: 10.1016/j.childyouth.2020.104954.

Park, N., Peterson, C. and Al, P. E. T. (2004) 'Strenghts of character and well-being', Journal of Social and Clinical Psychology, 23(5), pp. 603-619.

Peterson, C. and Seligman, M. E. P. (2004) Character strengths and virtues: A handbook and classification. United States of America: American Psychological Association.

Ramdani, Z. (2018) 'Construction of academic integrity scale Implementation School Inclusion View project Psychometric Properties of Psychological Constructs View project Construction of academic integrity scale Construction of academic integrity scale', International Journal of Research Studies in Psychology, 7(1), pp. 87-97. doi: 10.5861/ijrsp.2018.3003.

Ramdani, Z., Amrullah, S. and Tae, L. F. (2019) 'Pentingnya kolaborasi dalam menciptakan sistem pendidikan yang berkualitas', MEDIAPSI, 5(1), pp. 40-48.

Ramdani, Z. and Prakoso, B. H. (2019) 'Integritas akademik: Prediktor kesejahteraan siswa di sekolah', Indonesian Journal of Educational Assesment, 2(1), p. 29. doi: 10.26499/ijea.v2i1.14.

Ramdani, Z., Marliani, R., \& Rahman, A. A. (2019) 'The individual work perfomance scale: A psychometric study and its aplication for emloyee performance', Humanities \& Social Sciences Reviews, 7(5), pp. 405-414. doi: 10.18510/hssr.2019.7545

Smokowski, P. R. et al. (2014) 'Ethnic Identity and Mental Health in American Indian Youth: Examining Mediation Pathways Through Self-esteem, and Future Optimism', Journal of Youth and Adolescence, 43(3), pp. 343-355. doi: 10.1007/s10964-013-9992-7.

Sternberg, R. J. (2010) 'Why Schools Should Teach for Wisdom: The Balance Theory of Wisdom in Educat...: University of Warwick eResources', Educational Psychologist, 36(4), pp. 227-245. Available at: http://0-eds.b.ebscohost.com.pugwash.lib.warwick.ac.uk/eds/pdfviewer/pdfviewer?vid=2\&sid=6db070f4-59d9-40afb54f-5f949e42d2f4\%40sessionmgr103.

Toner, E. et al. (2012) 'Character strengths and wellbeing in adolescence: Structure and correlates of the Values in Action Inventory of Strengths for Children', Personality and Individual Differences. Elsevier Ltd, 52(5), pp. 637-642. doi: 10.1016/j.paid.2011.12.014.

Warsihna, J., Ramdani, Z., \& Prakoso, B. H. (2019) 'Using Kahoot to improve students' achievement and critical thinking in undergraduate of psychology students', IADIS International Conference Cognition and Exploratory Learning in Digital Age 2019, pp. 144-150. 